\title{
Lending a Helping Hand
}

(Continued from page 31 )

every hunter will be familiar with this bird. As a personal obligation he will then prevail upon his hunting friends to be on the alert for these birds and report their appearance. He should discuss the plight of the Whoopers and be willing to refrain from shooting any white bird. In some areas this will need special attention, for it is legal to shoot the Snow Goose in season, but in some areas we also have the very rare Ross's Goose - of which not more than fifteen hundred exist and they will be travelling with the other Snows. Who will think of the difference in the excitment of Goose hunting? It would be a small sacrifice to give up shooting Snow Geese in this very local area and a great contribution towards the survival of these noble creatures.

At the moment we do not have cooperators in the Conservation and Game departments of North Dakota, South Dakota and Kansas. We hope we will, in the next edition, be able to announce further workers.

\section{Stone Hammer}

By Marion Nixon, Wauchope

A stone hammer, found on this farm many years ago, has the same shape as one illustrated in Blue Jay, Page 29. i.e. the grove does not extend completely around the circumference, though more nearly at the centre than on the one shown. One third of the stone, approximately, has a deposit over it of what looks like a lime and mud coating. This is particularly noticeable where the deposit is about.1/16 inch thick in the groove it crosses. (about two inches wide, heavy, and a further inch of light deposit, within the groove.) This layer of deposit has been chipped away from the original stone in several places.

We often remark on this heavily pebbled limey incrustation on the ficld stone, for it is as often on the under side of the stones as on top, where they lie imbedded in the earth. This must indicate that the lime deposit was on them before they were moved by glacial ice to their present scattered positions over our fields.
Recently we learned of an area on the Alberta Northeast Territories border where Whooping Cranes with young have been seen. The general location as it appeared in the press is reprinted here. This area is established as a Wood Buffalo National Park and affords reasonable security on both ends of the migration routes; our job will be to give them every assistance while migrating.

We would appreciate having full information concerning observations. Send them to your nearest conservation department. To sportsmen we suggest you tell your friends about this rare bird. Refrain from shooting any white bird unless you are absolutely sure it is a game bird that can be legally taken. No doubt the most of the fifty-three young have died as a result of gun shot. Let's see what can be done in the next ten years. It's up to us from here on.

\section{Co-operative Bird Migration Study}

\author{
By FRED BARD, Regina
}

(Too late for classification)

April 16th - Canada Goose

March 20 - Marsh Hawk

April 9th - Killdeer

April 24th - Mourning Dove

May 28th - Nighthawk

Ruby-throated Hummingbird

April 16th - Yellow-shafted Flicker

May 18th - Eastern Kingbird

Eastern Phoebe

May 11th - Barn Swallow

June 1st - Purple Martin

March 21st - American Crow

May 19th - House Wren

May 18th - Catbird

May 15th - Brown Thrasher

Red-eyed Vireo

Black \& White Warbler

May 15th - Yellow Warbler

April 25th - Mystle Warbler

Ovenbird

May 27th - Redstart

April 12th - Red-winged Blackbird May 18th - Baltimore Oriole

Rose-breasted Grosbeak

May 25th - Goldfinch

April 5th - Slate-coloured Junco

May 9th - Chipping Sparrow

May 2nd - White-crowned Sparrow

May 2nd - White-throated Sparrow 